\title{
THE CANADIAN JUDICIAL APPROACH TO EQUALITY RIGHTS: FREEDOM RIDE OR ROLLER COASTER?
}

\author{
M. DAVID LePofSKY* \\ I \\ INTRODUCTION
}

It is common for trends to emerge in the approach which a country's judiciary takes to a particular field of law, and for that approach to evolve gradually over time. Different judicial eras can often be delineated, at times reflecting changes in the membership of a nation's highest court. In the equality rights field, the pattern which emerges in Canada is best characterized as a fast-moving, accelerating roller coaster ride.

At times, Canada's courts, led by the Supreme Court, have reached unprecedented heights in the effective recognition of the nature of inequality and discrimination, and the sensitive and forceful implementation of legal doctrine to ensure its effective eradication. At other points, Canadian courts have manifested an unduly narrow, restrictively technical and strikingly insensitive response to equality rights. These diverging and contradictory approaches have become virtually contemporaneous in the past few years. They leave equality-seekers in Canada, those disadvantaged by virtue of race, sex, disability, age, and other similar causes, confused about the scope of their legal protection, uncertain about the extent to which Canada's courts will protect them from unlawful and unconstitutional discrimination, and ambivalent about the capacity of law and justice systems to promote equality.

This article's purpose is to survey the path which the Canadian judiciary has taken on the road to equality. It seeks to answer the question whether and to what extent Canada's courts have employed Canadian law to combat discrimination effectively and to achieve equality for the disadvantaged in society. This path is surveyed by examining a series of periods, which have been typified by ups and downs, and by twists and turns, akin to a roller coaster ride. The eras are surveyed in sequence, leading up to the great breakthroughs in the 1980s and the most recent, sharp plunge downward in 1990.

Copyright $\odot 1992$ by Law and Contemporary Problems

* Counsel, Constitutional Law and Policy Division, Ontario Ministry of the Attorney General.

This article was written in the author's personal capacity and does not represent the views of Ontario's Attorney General or his Ministry. The author acknowledges with thanks the invaluable assistance of Jeffrey Kehoe and Ian Peach, particularly with footnotes and editorial suggestions. 


\section{The Earliest Years-A Rapid Downward Plunge}

For the vast preponderance of Canadian history, the protection of equality rights was situated close to the bottom of the judicial priority list. Over the first ninety years of Canada's history, courts generally did not infuse egalitarian values or protection into either Canadian constitutional or common law. This was so despite the potential availability of these legal tools to redress, at least to a limited extent, problems of discrimination.

Even though Canada's Constitution lacked an explicit bill of rights prior to 1982, the Supreme Court endeavored for a time to recognize in it an "implied bill of rights," replete with limited protections for freedom of expression, press, religion, and assembly. ${ }^{\prime}$ However, no judicial effort was undertaken to infuse equality guarantees for the disadvantaged and disenfranchised into this implied bill of rights. ${ }^{2}$ Indeed, efforts to attack the constitutionality of overtly racist legislative workplace restrictions, even based on federalism doctrines, tended typically to meet with failure in this century's earliest years. ${ }^{3}$

The common law in Canada, as in England, has often shown itself capable of evolving over time to create new doctrines which meaningfully respond to changes in society and social values. However, it demonstrated itself to be ineffectual in this regard insofar as protecting against discrimination. Efforts to invoke common law contract, tort, and property principles to attack racially discriminatory business practices met with failure, ${ }^{4}$ with one exception. In the 1940 s, an Ontario court invalidated a racially-based restrictive covenant on land. Even then, this result was achieved only on grounds of vagueness, and not on account of any judicial recognition of a public policy against discrimination. ${ }^{5}$ Indeed, in the current era of statutorily protecting against discriminatory practices, the Supreme Court has reaffirmed that such protections are entirely a creature of statute, and that equality-seekers can secure no assistance from the common law. ${ }^{6}$

With the judicial evolution of administrative law constraints on the exercise of governmental power at common law over this century, it was open to Canadian courts to fashion protections for equality rights, much as they crafted protections against deprivations of property or contractual rights. Yet, this generally did not happen. To the extent that an extremely limited

1. See Reference re Alberta Statutes, [1938] SCR 100, aff'd, [1939] AC 117; Saumur v Quebec, [1953] 2 SCR 299; Switzman v Elbling, [1957] SCR 285.

2. See Peter W. Hogg, Constitutional Law of Canada 635-38 (Carswell, 1985). There are no cases in which the Supreme Court considered infusing an equality rights guarantee into the implied bill of rights.

3. Cunningham and British Columbia (Attomey General) v Tomey Homma and Canada (Attorney General), [1903] AC 111 (PC); see also Irwin Cotler, Freedom of Assembly, Association, Conscience and Religion, in Gerald A. Beaudoin \& Ed Ratushny, eds, The Canadian Charter of Rights and Freedoms 165-91 (Carswell, 2d ed 1989).

4. See Loew's Montreal Theaters Lid. v Reynolds, 30 Que KB 459 (1919); Franklin v Evans, 55 OLR 349 (1924); Rogers v Clarence Hotel, [1940] 2 WWR 152.

5. Re Drummond Wren, [1945] OR 778 .

6. See Seneca College v Bhadauria, [1981] 2 SCR 181, 188. 
common law rule against the enactment of discriminatory municipal bylaws has been judicially enunciated, this doctrine has served only to protect businesses against seemingly arbitrary or irrational regulation of their hours or venue of business. ${ }^{7}$

As a result of mounting legislative recognition of the destructiveness of the most virulent manifestations of discrimination in society around the time of World War II, provincial legislatures slowly began to enact piecemeal legislation prohibiting certain forms of racial and religious discrimination. These legislative initiatives proliferated in the $1950 \mathrm{~s}$, making certain denials of equality offenses punishable by prosecution in court. ${ }^{8}$ However, they were considered largely ineffectual at redressing social inequalities. ${ }^{9}$

A core defect with these laws was that their enforcement was left to the courts. One had to present discrimination claims by way of individual prosecutions. Canada's criminal justice system generally did not provide a receptive haven for those seeking redress from discriminatory practices. ${ }^{10}$

\section{III}

\section{From 1960 to 1981 -The First Ascent and the Downward Runs}

Perhaps the greatest stride forward on the Canadian road to equality occurred between 1960 and 1981, when provincial legislatures, followed by the federal Parliament, decided to take the job of protecting minorities from discrimination predominantly out of the hands of the judiciary and to assign it to new, specialized administrative agencies. These human rights commissions and boards were charged with responsibility for investigation, mediation, and adjudication of discrimination claims in economic fields such as access to jobs, housing, goods, and services. ${ }^{11}$ The agencies and administrative tribunals were gradually armed with progressively-expanded legislative mandates to address newly recognized problems of discrimination based on such grounds as gender, age, marital status, and, more recently, disability, receipt of social assistance, and sexual orientation. ${ }^{12}$

7. See City of Montreal v Arcade Amusements, [1985] 1 SCR 368; Re Bunce and Town of Cobourg, [1963] 2 OR 343.

8. See, for example, Racial Discrimination Act, SO 1944, ch 51 ; Saskatchewan Bill of Rights Act, SS 1947, ch 35; The Fair Employment Practices Act, SO 1951, ch 24; The Fair Accommodation Practices Act, SS 1956, ch 68.

9. Walter S. Tarnopolsky \& William F. Pentney, Discrimination and the Law 2-3 through 2-6 (Richard De Boo, 1985).

10. Id at 2-1 through 2-14; see also Cameron v Nel-Gor Castle Nursing Home, 5 CHRR D/2170 (Ont Bd of Inquiry, 1984).

11. Tarnopolsky \& Pentney, Discrimination and the Law at 2-1 through 2-14 (cited in note 9).

12. The original Human Rights Code was passed in Ontario in 1961-62. Ontario Code of Human Rights, SO 1961-62, ch 93. Thereafter, each province passed similar legislation and thereafter amended it repeatedly. Current statutes are: Canadian Human Rights Act, RSC 1985, ch H-6; British Columbia Human Rights Act, SBC 1984, ch 22: Alberta Individual Rights Protection Act, RSA 1980, ch I-2 (as amended); Saskatchewan Human Rights Code, SS 1979, ch 5-241 (as amended); Manitoba Human Rights Code, CSM, ch H 175; Quebec Charter of Human Rights and Freedoms, RSQ 1977, ch C-12 (as amended); New Brunswick Human Rights Code, RSNB 1973, ch H-11 (as amended); Nova Scotia Human Rights Act, SNS 1969, ch 11 (as amended); Prince Edward 
Human Rights Commission staff and the jurists impanelled as adjudicators on the tribunals which decide discrimination cases developed extensive expertise in identifying subtle and overt discrimination, and in fashioning effective remedies to correct it. A burgeoning, voluminous human rights jurisprudence has evolved. It elucidates an indigenous set of substantive, procedural, and evidentiary doctrines sensitively tailored to achieve the important goals of human rights legislation. ${ }^{13}$

This transfer of the vast preponderance of anti-discrimination work from courts to administrative agencies met with success. ${ }^{14}$ These agencies grew in size as their case loads proliferated and as their task's subtle complexity became more manifest. Yet, over the 1960s and 1970s, some responsibility for the enforcement of equality rights was still reposed in Canada's judiciary, emanating from two legal sources. In each of these, the judicial performance in charting an expeditious path down the road to equality was not substantially better than it had been in the first half of this century. Indeed, it rather resembled a roller coaster's sharp downward plunge.

The first residual source for judicial responsibility over equality rights was the statutory Canadian Bill of Rights, ${ }^{15}$ a federal law enacted in 1960 to guarantee fundamental civil liberties against abridgement by the federal government. The Bill guarantees in section $1(b)$ the right to equality before the law and the protection of the law, and ensures in the opening words of the section that this right, along with the others listed in section 1, exists without discrimination by reason of race, national origin, colour, religion, or sex. ${ }^{16}$ The Bill of Rights expressly prevails over all federal legislation, except for those statutes which explicitly exempt themselves from its reach. ${ }^{17}$ Courts are under an explicit statutory duty to construe and apply federal laws in a fashion which ensures the protection of the rights and freedoms enumerated in the Bill. ${ }^{18}$

Though not exactly constitutional in scope, the Bill's lofty guarantees, expressed in sweeping and absolutist language, provided Canada's courts with a new, ample mandate to enforce such important rights as freedom from discrimination at the hands of the national government. Despite an initial signal from the Supreme Court that the Bill's equality guarantee was to be taken seriously, ${ }^{19}$ Canada's highest court proceeded to enunciate a series of doctrines which ensured its consummate failure. Taken together, these holdings decimated the Bill's equality guarantee in a fashion which seemed to reflect the prevailing judicial approach in the equality field in this century,

Island Human Rights Act, SPEI 1975, ch 72 (as amended); Newfoundland Human Rights Code, 1988, SNfld 1988, ch 62; Ontario Human Rights Code, 1981, SO 1981, ch 53 (as amended).

13. This jurisprudence can be found in the Canadian Human Rights Reporter series.

14. Tarnopolsky \& Pentney, Discrimination and the Law at chs 14, 15 (cited in note 9). See generally Judith Keene, Human Rights in Ontario (Carswell, 1983).

15. RSC 1970, App III at 457-60.

16. Id at $\S 1$.

17. Id at $\$ 2$.

18. Id.

19. See R. v Drybones, [1970] SCR 282. 
rather than reflecting any serious effort to ascertain and implement the legislative intent underlying the Canadian Bill of Rights.

The Supreme Court in effect held that courts should be exceedingly deferential to the will of Parliament in assessing the compatibility of federal laws with the Bill, even though it was Parliament itself which had commanded the courts to enforce the Bill's guarantees. ${ }^{20}$ The Court held that while section l(b) of the Bill guaranteed a right to equality, this right was not egalitarian in nature. ${ }^{21}$ It held that equality rights were inapplicable to laws extending benefits to the public, ${ }^{22}$ and that any differential treatment mandated under federal law was unassailable so long as it was relatable to a legislative purpose which falls within the constitutional jurisdiction of the federal government-a test which all constitutionally valid federal laws necessarily can pass. ${ }^{23}$

The second residual source of judicial authority concerning equality rights during this period was the courts' power to supervise provincial human rights agencies and tribunals through administrative law doctrines and, in some instances, through statutory appellate jurisdiction. Though less obvious here than in the Canadian Bill of Rights context, judicial performance in this field did not reflect any greater vigour in the enforcement of equality rights, at least insofar as the Supreme Court of Canada was concerned. At this time, the Supreme Court was clearly not in the forefront of the effort to ensure forceful implementation of the legislative commitment to equality set forth in human rights statutes.

There is very little in the way of Supreme Court jurisprudence in the Human Rights Code context before 1980. The most extensive treatment involved an extremely restrictive approach to such legislation. In Gay Alliance Towards Equality v. Vancouver Sun, ${ }^{24}$ the Supreme Court rejected a complaint of discrimination with respect to services offered to the public brought by a homosexual group against a daily newspaper. The paper had refused to run the organization's advertisement on sexual orientation grounds.

Because the human rights statute in question had an open-ended equality guarantee, the case raised the question whether discrimination because of sexual orientation was prohibited by the statute. The majority ducked this question. It decided the case instead on the ground that a statutory guarantee against discrimination with respect to services customarily available to the public simply did not apply to advertising space in a newspaper, even though newspapers routinely offer such space for sale to the public.

20. See, for example, Curr $v$ the Queen, [1972] SCR 889 (per Laskin); Canada (Attorney General) $v$ Lavell, [1974] SCR 1349.

21. See Lavell, [1974] SCR at 1365 (per Ritchie).

22. Bliss v Canada (Attorney General), [1979] I SCR 183, 192-94.

23. Id. An apparent retreat from this extremely minimal standard of review was suggested in the concurring opinion of Justice McIntyre in MacKay v the Queen, [1980] 2 SCR 370, 407, although the Charter's advent eclipsed this late jurisprudential development. In subsequent Charter cases, the Supreme Court acknowledged that the Canadian Bill of Rights had generally received a very narrow judicial interpretation. See, for example, Singh v M.E.I., [1985] I SCR 177 (Wilson concurring).

24. [1979] 2 SCR 435. 
In construing "services" extremely narrowly to apply essentially to restaurants, hotels, and the like, the majority ironically invoked freedom of speech as a partial support for its decision. This was impossible to square with the Canadian approach to free speech at that time. There was then no explicit constitutional guarantee of freedom of speech in effect in Canada. The limited free speech guarantee in the "implied bill of rights" jurisprudence was by then judicially discarded. ${ }^{25}$ The Canadian Bill of Rights, which the majority actually cited, did not apply to the provincial statute in issue in that case. In short, the Supreme Court's most detailed pronouncement on human rights before the $1980 \mathrm{~s}$ was insensitive to the value of equality and its fundamental importance in a democracy. It was purportedly justified by an invocation of free speech at a time when such invocation had no legal foundation.

\section{IV}

\section{The 1980s-The Supreme Court's Sharp Ascents Towards Equality and the Lower Courts' Descents}

This long-term trend against active judicial enforcement of equality rights took an extraordinarily sharp turn at the start the 1980 s, primarily at the direction of the Supreme Court of Canada. The 1980s was a decade of unprecedented Supreme Court activity targeted at providing vigorous equality rights protection, both in the statutory and constitutional contexts. It reflected a new and profound judicial commitment to the ideal of equality, and to the implementation of legislative mandates to see this ideal aggressively promoted.

The Supreme Court's accomplishments during this decade in the human rights field speak for themselves as a drastic break from the judicial past. Whereas the statutory Canadian Bill of Rights was relegated to virtual legal oblivion on account of concerns about parliamentary sovereignty, the Supreme Court ruled that human rights statutes are essentially quasiconstitutional in character. ${ }^{26}$ The egalitarian commands of these statutes take firm precedence over all other legislation, except where a contrary legislative intent is clearly manifested. Human rights statutes must receive a large and liberal interpretation to root out the social blight of discrimination effectively. ${ }^{27}$ Any statutory exceptions to human rights guarantees must be construed narrowly, to the same end. ${ }^{28}$

Lower court rulings had strictly confined human rights protection to clear cases of overtly intentional or purposive discrimination, despite a broader approach to equality having emanated from human rights boards of inquiry. ${ }^{29}$

25. Canada (Attorney General) v Dupond, [1978] 2 SCR 770.

26. Ontario Human Rights Commission v Simpsons-Sears, Ltd, [1985] 2 SCR 536, 547.

27. Id at 546-47; see also Ontario Human Rights Commission v Etobicoke, [1982] 1 SCR 202.

28. See, for example, Etobicoke, [1982] I SCR at 212.

29. Compare, for example, Simpsons-Sears, 36 OR (2d) 59 (Div Ct 1982), aff'd, 38 OR (2d) 423 (CA 1982), with O'Malley v Simpsons-Sears, Ltd., 2 CHRR D/267 (Ont Bd Inquiry 1981 ). 
In powerful contrast, the Supreme Court ruled that the concept of equality in such legislation goes much further. It prohibits both intentional and unintentional discrimination, the latter also being called constructive or "adverse effects" discrimination. ${ }^{30}$

According to the Supreme Court, legislative injunctions against discrimination impose an affirmative duty to accommodate the special needs of racial, religious, and other minorities, where their full and equal participation in employment and other like economic opportunities is impeded by neutral requirements with discriminatory effects, and where accommodation would not impose undue hardship on the party imposing the unintentionally discriminatory barrier. ${ }^{31}$ Obscure and abstruse statutory interpretation concerns initially led the Court, in the mid 1980s, to restrict this liberal approach to constructive discrimination to only some of Canada's human rights statutes. ${ }^{32}$ However, a later decision removed these technical impediments and infused the duty to accommodate into all such legislation, with a high standard of justification demanded of defendants who claim that accommodation cannot be achieved short of undue hardship. ${ }^{33}$

Augmenting these important advances were critical Supreme Court sex equality decisions during this decade. The Court held that discrimination because of pregnancy is, in substance, sex discrimination. ${ }^{34}$ This effectively overruled a previous, highly formalistic, and widely criticized ruling in 1979 under the Canadian Bill of Rights to the effect that pregnancy-based discrimination denies equality to pregnant people, though not on account of their gender. ${ }^{35}$ The Court also ruled that sexual harassment in the workplace constitutes sex discrimination, thereby extending the right to equality beyond the simple formalization of the work relationship to the substance of the entire work environment. ${ }^{36}$ Finally, the Court affirmed the broad mandate of human rights tribunals to shape sweeping remedies to rectify systemic discrimination by upholding a tribunal's imposition of substantial affirmative action or employment equity remedies on an employer with a bad track record of systemic sex inequality. ${ }^{37}$ These gender equality decisions at times involved the Supreme Court intervening to re-institute the liberal approach to equality rights protection created by a human rights tribunal but overturned by a lower court. ${ }^{38}$

In tandem with this decade's important human rights developments was the Supreme Court's initial enunciation of general principles for the interpretation of Canada's new constitutional Charter of Rights and

30. Simpsons-Sears, [1985] 2 SCR at 547-50.

31. Id at 552-56.

32. Compare id with Bhinder v Canadian Natl Railway, [1985] 2 SCR 561.

33. Alberta Human Rights Commission v Central Alberta Dairy Pool, [1990] 2 SCR 489.

34. Brooks v Canada Safeway Ltd., [1989] I SCR 1219.

35. Bliss v Canada (Attorney General), [1979] I SCR 183.

36. Robichaud v Canada (Treasury Board), [1987] 2 SCR 84, 92.

37. Canadian Natl Railway v Canada Human Rights Commission, [1987] I SCR 1114.

38. Canadian Natl Railway v Canada Human Rights Commission, [1985] I FC 96; Brennan v The Queen, [1984] 2 FC 798. 
Freedoms, enacted in 1982 as part of Canada's supreme law. ${ }^{39}$ The Charter includes a broadly worded guarantee in section 15(1) of equality "before and under the law" and the "equal protection and equal benefit of the law without discrimination and, in particular, without discrimination based on race, national or ethnic origin, colour, religion, sex, age or mental or physical disability."40 This provision includes an exception in section 15(2) to preserve the constitutionality of affirmative action programs, that is, laws, programs, and activities whose objective is the amelioration of the conditions of disadvantaged persons or groups, including those disadvantaged because of their race, religion, or other characteristics enumerated in section $15(1) .^{41}$ Charter section 1 also preserves as constitutional any "reasonable limits" on Charter rights which are "prescribed by law" and which "can be demonstrably justified in a free and democratic society." 42

For the most part, lower courts initially took a firm "wait and see" attitude towards the Charter. They often construed it quite narrowly, akin to the statutory Canadian Bill of Rights, until the Supreme Court directed otherwise. $^{43}$ In its earliest Charter pronouncements, the Supreme Court forcefully indicated that the Charter must be taken seriously, as a substantial departure from the Canadian Bill of Rights experience. ${ }^{44}$ The Court held that Charter rights must be construed liberally and purposively, ${ }^{45}$ and that limits on these rights, imposed under section l's reasonable limits clause, shall be held to a strict justificatory standard. ${ }^{46}$ Pursuant to the section 1 test specified in the case of Regina $v$. Oakes, ${ }^{\mathbf{7}}$ governmental limits on civil liberties are constitutionally sustainable only if they are clearly prescribed by a law that is

39. Can Const (Constitution Act, 1982) pt I (Canadian Charter of Rights and Freedoms).

40. Section 15(1) of the Charter provides as follows:

Every individual is equal before and under the law and has the right to the equal protection and equal benefit of the law without discrimination and, in particular, without discrimination based on race, national or ethnic origin, colour, religion, sex, age or mental or physical disability.

41. Section $15(2)$ of the Charter provides as follows:

Subsection (1) does not preclude any law, program or activity that has as its object the amelioration of conditions of disadvantaged individuals or groups including those that are disadvantaged because of race, national or ethnic origin, colour, religion, sex, age or mental or physical disability.

42. Section 1 of the Charter provides as follows:

The Canadian Charter of Rights and Freedoms guarantees the rights and freedoms set out in it subject only to such reasonable limits prescribed by law as can be demonstrably justified in a free and democratic society.

43. See, for example, Re Regina and Potma, 37 OR (2d) 189 (HCJ 1982); $R$. $v$ Morgentaler, 12 DLR (4th) 502 (Ont SC 1984), appeal quashed, 14 DLR (4th) 184 (Ont CA 1984); R. v Banville, 145 DLR (3d) 595 (NBQB 1983), varying 141 DLR (3d) 36 (NB Prov Ct 1982); Re Global Communications and Canada (Attorney General), 44 OR (2d) 609 (CA 1984); Re Cromer and BC Teachers' Federation, 5 WWR 638 (BCA 1986).

44. Law Society of Upper Canada v Skapinker, [1984] 1 SCR 357; Hunter v Southam Inc., [1984] 2 SCR 145; Singh v M.E.I., [1985] I SCR 177 (Wilson); R. v Big M Drug Mart Ltd., [1985] 1 SCR 295.

45. Hunter, [1984] 2 SCR at 156.

46. Big $M$ Drug Mart Lid., [1985] 1 SCR at 295.

47. R. $v$ Oakes, [1986] I SCR 103, 105-06. 
not vague, ${ }^{48}$ if they are narrowly and carefully tailored to achieve pressing and substantial societal goals which are of sufficient importance to warrant the overriding of Charter rights, if they are trimmed to impair Charter rights as little as possible, and if they are proportionate to their objectives.

Although the implementation date of the Charter's equality guarantee was deferred for three years to $1985,{ }^{49}$ the Supreme Court's earliest pre-section 15 Charter rulings foreshadowed a strong commitment to constitutional protection against discrimination. This paralleled the Court's new dedication to the success of statutory human rights guarantees. The Court declared that the Charter's rights must be liberally construed to achieve the Constitution's goal of securing for Canada a free and democratic society, and underscored that a core component of this goal is the fostering of equality and social diversity. ${ }^{50}$ Thus, equality, which had played so minimal a role in Canadian law over most of our history, has been elevated to a pivotal ingredient of our Constitution's very raison d'etre.

The Supreme Court also proclaimed in advance of section 15's coming into force that equality, as a constitutional construct, is sweeping in scope. It is not simply restricted to purposive or intentional governmental discrimination. It includes protection against discriminatory effects of legislation and other government action. This emanates from the Court's ruling in a freedom of religion case that equality can well require different treatment of individuals and groups. ${ }^{51}$

With the Supreme Court's strong signals about equality's new primacy, Charter section 15's 1985 advent could have been expected to yield immediate and substantial new protections from lower courts in favour of women, disabled persons, and other disadvantaged minorities. Yet this was not to be. Before the Supreme Court first decided a Charter section 15 case, lower courts quickly bogged down in the enunciation of abstruse and ineffectual tests for defining Charter equality rights.

Some lower courts defined equality as requiring governments to treat persons similarly situated in a similar fashion. 52 Others found discrimination to exist wherever a law differentiated between two groups of persons, however delineated, where the law's purpose was adjudged to be unreasonably, irrationally, or unfairly connected to its means. ${ }^{53}$ At times, these tests were redefined each time they were applied. ${ }^{54}$

48. The vagueness principle was first enunciated in Re Ontario Film and Video Appreciation Society $v$ Ontario Board of Censors, 147 DLR (3d) 58 (Ont Div Ct 1983), and was later recognized by the Supreme Court in Reference re Criminal Code (Man), [1990] I SCR 1123, 1150.

49. Charter $\$ 32(2)$.

50. Oakes, [1986] I SCR at 136.

51. Big M Drug Mart, [1985] 1 SCR at 347 (Dickson).

52. See, for example, $R$. $v$ Century 21 Ramos Realty Inc. and Ramos, 58 OR (2d) 737 (CA 1987); $R$. $v$ Ertel, 35 CC (3d) 398 (Ont CA 1987).

53. See, for example, Wilson v British Columbia Medical Services Commission, 30 BCLR (2d) 1 (BCSC 1988), rev'd on other grounds, 53 DLR (4th) 171 (BCA 1988).

54. See id and the cases cited in note 52 . 
By these various tests, the vast preponderance of lower court constitutional equality litigation involved business challenges to regulatory legislation impeding their unrestricted pursuit of profit, and criminal accused's challenges advancing procedural due process concerns in the guise of equality issues. ${ }^{55}$ Equality cases quickly degenerated into litigation over the wisdom of impugned laws, pure and simple, wholly unconnected to the Canadian human rights tradition from which section 15 sprang. ${ }^{56}$ This jurisprudence roughly paralleled the United States' "rational basis" test for minimal scrutiny under the fourteenth amendment's equal protection clause, with one critical difference. In the United States, minimal scrutiny is overwhelmingly, though not entirely, associated with extreme judicial deference for, at times, virtually unintelligible legislative distinctions. ${ }^{57}$ In Canada, "rationality review" translated into judicial "adhocracy," with unpredictable, simultaneous bouts of judicial interventionism and judicial restraint. ${ }^{58}$

This earliest round of section 15 cases yielded little for women and the other disadvantaged groups enumerated in section 15 for particular protection from discrimination. For example, men often secured more than women from sex equality. ${ }^{59}$ One court solved the problem of provincial social assistance available to women but not men by taking the welfare entitlement away from women. ${ }^{60}$ There, constitutional equality meant judicially-imposed impoverishment for all. Similarly, disabled persons secured little optimism from the lower courts' section 15 approach. Nineteenth-century criminal legislation requiring the indefinite detention of criminal accuseds found unfit to stand trial or not guilty by reason of insanity was upheld, whether or not those incarcerated remained either mentally disordered or dangerous, and regardless of the triviality of their offenses. ${ }^{61}$

From the perspective of women, disabled persons, and other disadvantaged groups seeking equality under the Charter, the lower courts' approach to equality in this initial section 15 jurisprudence was to a degree a throwback to the judicial treatment of equality prevailing in the earlier part of this century. For them, a critical breakthrough occurred when the Supreme Court first ruled on section 15 claims in the latter part of the 1980s. The highest court enunciated several core section 15 doctrines in two decisions.

55. See id; Re Aluminum Co. of Canada and the Queen in right of Ontario, 29 DLR (4th) 583 (Ont Div Ct 1986); Institute of Edible Oil Foods $v$ Ontario, 47 DLR (4th) 368 (1987), aff'd on other grounds, 64 DLR (4th) 380 note (Ont CA 1988).

56. M. David Lepofsky \& Schwartz Hart, An Erroneous Approach to the Charter's Equality Guarantee: Regina v. Ertel, 67 Canadian Bar Rev 116, 126 (1988).

57. See Williamson v Lee Optical of Oklahoma, 348 US 483 (1955); United States Railroad Retirement Board v Fritz, 449 US 166 (1980).

58. See cases cited in note 55; see also $R$. $v$ Hamilton, 30 CC (3d) 257 (Ont CA 1986) (Morden); Hutton v Ontario (Attorney General) (Ont CA March 7, 1990) (unreported).

59. Shelagh Day \& Gwen Brodsky, Canadian Charter Equality Rights for Women: One Step Forward or Two Steps Back (Canadian Advisory Council on the Status of Women, 1989).

60. Nova Scotia (Attorney General) et al. v Phillips, 34 DLR (4th) 633 (NSSC 1986); see also Reference Re Family Benefits Act (NS) $\& 5,75$ NSR (2d) 338 (1986).

61. R. v Swain, 53 OR(2d) 609 (CA 1986). 
These decisions were Law Society of British Columbia v. Andrews ${ }^{62}$ (striking a provincial statute categorically excluding non-citizens from the practice of law in British Columbia) and Turpin $v$. the Queen ${ }^{63}$ (upholding a federal criminal code section that allowed an individual charged with an indictable offence in Alberta to be tried by judge alone.)

The Andrews/Turpin approach to equality ensures that section 15's protection focuses squarely on those discrete and insular groups in society who have been disadvantaged because of a personal attribute. As a matter of general approach, the Supreme Court acknowledged that section 15 of the Charter is tied closely to the evolution of human rights protection in Canada, and that it aims to ensure equality of opportunity at the hands of government to persons disadvantaged in society because of their race, sex, religion, or other analogous personal characteristic. ${ }^{64}$ Contrary to the approach taken in many lower courts, the Charter's equality guarantee was held not to embroil the Court in reviewing the merits of all legislative distinctions between individuals or groups, and was not a mandate for the wholesale judicial review of all statutes to test their rationality as such. ${ }^{65}$ The Supreme Court categorically rejected the "similar treatment for persons similarly situated" test, employed predominately in Ontario courts, as wholly unsuited to the task of achieving section 15's objectives. ${ }^{66}$

The Andrews/Turpin approach properly limits the grounds of discrimination which are actionable under the Charter. Section 15's text enumerates nine prohibited grounds of discrimination, and leaves it to courts to add other "unenumerated" grounds to this non-exhaustive list. The Supreme Court rejected any possibility that the list of actionable grounds of discrimination is infinite or that all legislative distinctions are constitutionally suspect under section 15. Instead, it held that the only grounds of discrimination which are actionable beyond the enumerated grounds are those which are "analogous" to them.67

The Supreme Court provided some inkling of the analysis to be used for deciding whether a proffered ground of discrimination, not found in section 15's text, is "analogous," although no attempt was made to be systematic or exhaustive. Various justices considered whether a proposed ground of discrimination pertains to a personal characteristic and whether it relates to a discrete and insular minority which has suffered from stereotyping and political or social disadvantage, independent of the particular impugned law. 68

62. [1989] I SCR 143.

63. [1989] 1 SCR 1296.

64. Andrews, [1989] 1 SCR at 170.

65. Id at 168 (McIntyre).

66. Id at 167-68; Turpin, [1989] 1 SCR at 1332 (Wilson). This approach had been used predominantly in the Ontario Courts.

67. Andrews, [1989] I SCR at 182; Turpin, [1989] I SCR at 1332; see also Reference re Workers Compensation Act, 1983 (Newfoundland), [1989] I SCR 922.

68. Andrews, [1989] 1 SCR at 183 (McIntyre); id at 152 (Wilson); see also Turpin, [1989] I SCR at 1330-33 (Wilson). 
To develop this analysis into a manageable test which lower courts can systematically apply and governments can reasonably foresee, criteria for determining whether a ground is "analogous" can be expanded. They can include consideration of whether the ground has been recognized in existing human rights statutes or other anti-discrimination laws, whether Canada is under an international obligation to eliminate a certain genre of discrimination, and generally, whether the ground is analogous in the sense that it involves either an intimate, immutable physical attribute or a fundamental personal choice, akin to one's religion, which is constitutionally immunized from state intrusion.

The enumerated grounds in section 15 should not be treated as having been included by accident or coincidence, as had been the case under the "similarly situated" approach to equality. ${ }^{69}$ Rather, they should serve as a clear guidepost as to the kinds of discrimination at which section 15 was targeted. A plaintiff, seeking a judicial expansion of section 15's grounds to include a particular unenumerated ground, should be required to adduce contemporary or historical proof establishing the existence of the requisite factors. Government studies documenting a minority's disadvantaged status would be highly probative.

While this "analogous grounds" approach might be criticized for confining section 15's actionable grounds, such criticism is unwarranted. By so limiting the actionable grounds, the Supreme Court ensured that the full force of section 15 could be targeted at protecting those disadvantaged groups whom it was intended to serve, while leaving manageable breathing room for legislative activity and for judicial recognition of additional groups requiring equality rights protection, as experience accumulates. This tracks closely the development of human rights legislation in Canada, whose recognition of groups deserving protection from discrimination has evolved gradually. The Andrews/Turpin approach also effectively roots out the plethora of section 15 economic and business distinction and criminal due process cases which had so preoccupied lower courts, and which had improperly distracted from section 15's core task.

Contemporaneous with the focusing of section 15 on those groups truly needing its protection was Andrews/Turpin's assurance that the content of section 15's promise of equality to its beneficiaries is a generous one. Section 15 bans not only purposive discrimination, but unintentional or "adverse effects" discrimination as well. ${ }^{70}$ This makes section 15 far more potent than the United States' equal protection clause, which is restricted to purposive discrimination alone. ${ }^{71}$ This difference reflects the Canadian Supreme Court's recognition that systemic discrimination is in fact more pervasive than intentional discrimination in Canadian society. ${ }^{72}$

69. See note 55 .

70. Andrews, [1989] I SCR at 173 (McIntyre).

71. Washington v Davis, 426 US 229 (1976).

72. Canadian Human Rights Commission v Tavlor et al., 75 DLR (4th) 577, 603 (SC 1990) (Dickson). 
The Andrews/Turpin approach also requires that any effort by government to justify disadvantageous treatment based on an impermissible ground of discrimination must be defended under Charter section 1's reasonable limits clause, and not under section 15. The Supreme Court effectively discarded various lower court tests which obliged a Charter plaintiff to affirmatively prove that discrimination against her was either unfair, unreasonable, unjustified, unwarranted, or otherwise improper. ${ }^{73}$ Such an onus would have placed on equality seekers the difficult burden of justifying why they should be treated as equals, when the Charter itself makes such treatment a strong constitutional imperative. ${ }^{74}$

When the Andrews/Turpin analogous grounds test is juxtaposed with the Court's potent definition of equality, section 15 becomes an unprecedented promise of equality to the disadvantaged in Canada. Section 15 is extricated from the bog of rationality review cases which pervaded in the lower courts and in the United States. It avoids the prospect that the section 1 test would have to be seriously diluted, to the detriment of women and minorities, in order to save for government a reasonable latitude for legitimate legislation and governance. Andrews/Turpin also dismissed a U.S. style "levels of scrutiny" view of equality rights, which would have led some to enjoy more equality than others, and which would have placed courts in the unacceptable position of judging for themselves whose claims to equality among those recognized in section 15 are more important. ${ }^{75}$ It thus frees Canada from a jurisprudential quicksand in which the United States is now struggling to cope. ${ }^{76}$

It would again have been reasonable to expect lower courts to respond quickly to the Supreme Court's clear and strong directions on section 15. This was not to be the case for a time. Rather, some lower courts stiffly resisted the implementation of Andrews/Turpin by either attempting to narrow or distinguish it, or by mouthing its words without effectively applying it. ${ }^{77}$ This reticence again appears as a throwback to the pre-Andrews approach of ineffectual protection for equality which predominated in many lower courts. This initial response eventually gave way to a broader judicial acceptance of Andrews/Turpin,$^{78}$ and a commensurate disappearance of much of the section 15 litigation over business and economic regulation and criminal procedure laws which do not disadvantage women or the other groups mentioned in section 15 , or those similarly disenfranchised.

73. Andrews, [1989] I SCR at 178-80; for comparison, see $R$. $v$ Ertel, 35 CC (3d) 398; Wilson $v$ British Columbia Medical Services Commission, 30 BCLR (2d) 1 (BCSC 1988), rev'd on other grounds, 53 DLR (4th) 171 (BCA 1988).

74. See Lepofsky \& Hart, 67 Canadian Bar Rev at 122 (cited in note 56).

75. See especially Andrews, [1989] 1 SCR at 177-78 (McIntyre).

76. Cleburne, Texas v Cleburne Living Center, 473 US 432 (1985).

77. See, for example, R. v Paul Magder Furs Lid, 69 OR (2d) 172 (CA 1989) (Morden); Rheaumev Ontario (Allorney General), 63 DLR (4th) 241 (Ont HC 1989).

78. See, for example, Mirhadizadeh v Ontario, 69 OR (2d) 422 (CA 1989) 


\section{$\mathrm{V}$ \\ 1990-The Supreme Court's Unexpected Plunge Downward}

At the close of the 1980s, legislative and constitutional initiatives promoting equality rights together with their forceful judicial application by the Supreme Court of Canada (with some more reluctant lower courts at times lagging behind) combined to signal that the journey towards equality and away from discrimination was on a path strongly dedicated to the serious pursuit of these lofty goals. However, 1990 brought with it an abrupt and drastic change of judicial direction in the constitutional equality arena, at least at the Supreme Court level. This occurred in three important equality cases which indicate a sudden and marked retreat from the court's commitment to equality, and a fourth judgment released at the end of the year which provided a surprising twist in the equality roller coaster. These decisions are especially troubling, as it was the Supreme Court in the 1980s which was in the forefront of the effort to lead Canada's judiciary out of its historical quagmire in the equality field. Absent the court's continued leadership, the future in the constitutional sphere for Canada's equality seekers seems quite pessimistic.

\section{A. Hess v. Regina}

The first such reversal came in the court's finding in Hess $v$. Regina ${ }^{79}$ that a Criminal Code provision making it a crime for a male person over the age of fourteen to have sexual intercourse with a girl under the age of fourteen, does not even constitute prima facie sex discrimination contrary to Charter section 15 , and that as such, it requires no justification under section 1 . Speaking for a slim majority of 4 to 3 , Justice Wilson dismissed the section 15 sex equality claim, even though the impugned law defined the offence in a fashion so that only a male could commit it and only a female could be a victim of it, and despite the further fact that these gender delineations are spelled out explicitly in the provision. The Court held that there was no section 15 contravention because, as a matter of biological fact, only men could commit the act of sexual intercourse against female victims. ${ }^{80}$ Thus, according to Justice Wilson, the accused's sex was related to the law's purpose, and, in this regard, a female's sex could not possibly relate to the evil at which the law was aimed. ${ }^{81}$

Justice Wilson's section 15 analysis is an obvious application of the old "similarly situated/similarly treated" approach to equality which the Supreme Court, speaking at times through Justice Wilson herself, previously had rejected as entirely unsuited to the task of securing equality. ${ }^{82}$ What Justice Wilson held in effect in Hess is as follows: Parliament's purpose is to protect

79. [1990] 2 SCR 906.

80. Id at $929-30$ (Wilson).

81. Id at 929 .

82. Andrews, [1989] 1 SCR at 151-52 (Wilson). 
females under the age of fourteen from unwanted sex leading to pregnancy. From the perspective of this goal, men and women, as accused persons or as victims, are not similarly situated to each other. This is a matter of fact, and more particularly, a matter of "biological fact." Put another way, the accused did not establish that his sex is not reasonably related to the law's purpose. ${ }^{83}$ While Justice Wilson did not explicitly use the words "similarly situated," her discussion precisely parallels the "similarly situated" analysis of the Ontario Court of Appeal in a series of pre-Andrews/Turpin cases. ${ }^{84}$

Hess exposes some of the similarly situated test's inherent weaknesses. The test is a vacuous concept which does not dictate any specific result in any individual case. ${ }^{85}$ The Court could have held as readily that the impugned law's purpose is to protect children from sexual corruption by adults. In that event, men and women would have been treated unequally, and there would be no matter of biological difference between men and women as accuseds or victims which would relate to this legislative aim. In that event, the law would have violated section 15 and would have required a section 1 justification. ${ }^{86}$

Justice Wilson's approach implicitly places on Charter plaintiffs an onus under section 15 to show that they are not differently situated as a matter of fact from those who are not harmed by the impugned law, at least where the impugned legislative distinction pertains to a ground enumerated in section 15 or is analogous thereto. To disabled persons seeking equality under section 15, this would entail an unfair constitutional presumption of their difference from able-bodied persons. This directly contradicts Parliament's reasons for including disability in section 15 in the first place. ${ }^{87}$

The Hess decision should be treated as being of dubious jurisprudential value. On the section 15 point, the Court was badly split. Of the justices participating in the decision, those now remaining on the Court would be evenly divided on the point, since Justice Wilson's section 15 ruling was the subject of a strong dissent. As well, the majority's section 15 comments were entirely obiter dicta. The Court had invalidated the impugned law on other grounds, and need not have addressed the section 15 challenge at all to dispose of the appeal. ${ }^{88}$ Moreover, subsequent to Hess, the Supreme Court reiterated its firm rejection of the similarly situated test under section 15 , albeit without any reference to Hess. ${ }^{89}$

83. Hess $v R$., [1990] 2 SCR 906, 929.

84. See cases cited in note 55 .

85. See id.

86. This is not to suggest that the impugned law was unsalvageable under $\S 1$, but merely that the majority's "similarly situated" analysis precluded the need for $\$ 1$ analysis.

87. See note 56 and accompanying text; see also M. David Lepofsky \& Jerome E. Bickenbach, Equality Rights and the Physically Handicapped, in Anne F. Bayefsky \& Mary Eberts, eds, Equality Rights and the Canadian Charter of Rights and Freedoms 346-47, 353 (Carswell, 1985); M. David Lepofsky, Equality Rights for Handicapped Persons in the Charter, in Frank E. McArdle, ed, The Cambridge Lectures (Yvon Blais, 1987).

88. Hess, [1990] 2 SCR at 90.

89. See M/Kinney $v$ Board of Governors of the Liniversity of Guelph, [1990] 3 SCR 229. 


\section{B. The Mandatory Retirement Cases}

Perhaps the most catastrophic downward plunge on the Canadian equality roller coaster ride of equality came in December 1990 with the Canadian Supreme Court's decisions in four proceedings attacking the mandatory retirement of employees at age sixty-five. ${ }^{90}$ While the Supreme Court's treatment of equality under human rights statutes and the Charter in the 1980s boded well for the expansive enforcement of Charter equality rights for disadvantaged minorities, the mandatory retirement decisions intimate a massive reversal of direction in the constitutional context. Under them, the Charter's equality guarantee in section 15 may prima facie be meaty and meaningful. However, Charter section 1 ensures that the constitutional umbrella is taken away from victims of discrimination as soon as the rain starts to fall. This occurs through a serious dilution of the burden of justification placed on governments under section 1 when it is shown that section 15 equality rights are infringed.

Under attack in these cases were the mandatory retirement policies of universities, ${ }^{91}$ government-run community colleges, ${ }^{92}$ and a hospital. ${ }^{93}$ As well, two provincial human rights codes were challenged as themselves discriminating on account of age, because their legislative bans on age-based employment discrimination did not apply to persons aged sixty-five or older. ${ }^{94}$ One's recourse to the legal enforcement machinery of human rights commissions for age-based discrimination in employment was denied to persons sixty-five or older, purely on account of their age.

The Supreme Court split on whether Charter section 15 applies to private universities and hospitals, but unanimously agreed that it applies to government-run community colleges and to the age definition in human rights legislation. ${ }^{95}$ The Court unanimously held that where the Charter applies, the age distinctions vis-à-vis continued employment and access to human rights commissions contravene section 15 's equality rights guarantee. ${ }^{96}$ The Court's section 1 analysis, mainly expressed for the Court by Justice La Forest, includes several serious flaws. Those reviewed here pertain principally to the Court's method of applying section 1, and not to the merits of the question whether mandatory retirement could, under some circumstances, be constitutionally justified.

90. Id; Harrison v University of British Columbia, [1990] 3 SCR 451; Stoffman v Vancouver General Hospital, [1990] 3 SCR 483; Douglas/Kwantlan Faculty Ass'n v Douglas College, [1990] 3 SCR 570.

91. Harrison, [1990] 3 SCR at 451.

92. Douglas/Kwantlan, [1990] 3 SCR at 570.

93. Stoffman, [1990] 3 SCR at 483.

94. McKinney, [1990] 3 SCR at 229 (challenging $\$ 9(a)$ of the Ontario Human Rights Code); Harrison, [1990] 3 SCR at 45$]$ (challenging $\$ 1$ of the British Columbia Human Rights Act).

95. McKinney, [1990] 3 SCR at 275-76 (La Forest, writing for himself, Dickson, and Gonthier); concurring on this point are Justices Sopinka, id at 445, and L'Heureux-Dube, id at 419 ; see also id at 320 (Wilson dissenting on this point); id at 446 (Cory concurring with Wilson).

96. Id at 279 . 
1. The First Flaw. The mandatory retirement decisions' first flaw is the Court's improper grant of substantial deference under section 1 to legislative decisions in formulating and implementing human rights codes. The Court concluded that because a human rights statute's purpose is to advance the cause of equality between private parties in society, an aim tied to the Charter's own purposes, the Court should not intervene to compel the legislature to move towards this goal more quickly than it had planned. ${ }^{97}$ This judicial deference turns section 1 on its head, and disregards the core purposes for guaranteeing equality in a democracy.

Under section 1 , a government must shoulder a heavier burden when a Charter infringement is more severe. ${ }^{98}$ Severity can be measured in part by the extent to which a Charter right's infringement cuts to the quick of the purposes for which the affected constitutional right is entrenched in the Charter. In the equality context, the government's burden should increase, inter alia, where impugned legislative discrimination bears upon the exercise of fundamental rights. 99

Accordingly, the age definitions of the Ontario and B.C. human rights statutes demand especially compelling justification rather than judicial deference. The Supreme Court has characterized human rights statutes as fundamental, virtually quasi-constitutional legislation. ${ }^{100}$ What better proof could be provided of the pivotal nature of aged-based human rights protection than the fact that freedom from discrimination because of age also warrants entrenchment as a fundamental right in the Canadian Constitution. A legislative decision to deny a class of persons the protection of such fundamental legislation, simply because of their age, therefore bears directly on the exercise of a quintessentially fundamental entitlement in Canadian society, the freedom from discrimination, and cuts to the core of section 15 's purposes.

The right at stake, at least in the context of the challenges to age limitations in human rights statutes, is not the right to employment or to a job as such. It is the right to the protection of human rights legislation-the right to legal protection for the freedom from age-based discrimination. It is the right to one's access to an important administrative agency, and ultimately to the courts, to assert that one has been victimized by employment discrimination. It is the right to one's day in court on a vital issue. When so critical an entitlement is denied to a person on the explicit grounds of his or her age, and regardless of his or her individual capacity to profit from the

97. Id at 317-18.

98. Reference re Criminal Code (Man), [1990] 1 SCR at 1190 (prostitution reference).

99. This approach is reflected in U.S. equal protection doctrine. Under the equal protection clause of the 14 th amendment, a discriminatory law is subjected to more exacting scrutiny when it bears upon the exercise of fundamental rights than when it does not. See, for example, Skinner v Oklahoma, 316 US 535 (1942). Although there is much about American equal protection doctrine that is entirely unsuited to the Canadian constitutional context, this specific feature of U.S. equal protection doctrine makes eminent sense and should be infused into $\S 15$ analysis.

100. Simpsons-Sears, Ltd., [1985] 2 SCR at 541: Bhinder, [1985] 2 SCR at 586. 
responsible exercise of that right, section 1 demands the most compelling justification to ensure that the discriminatory denial of this right is absolutely required to serve critical societal goals. It is not to be shrugged off as lacking sufficient gravity.

To support the Court's grant of judicial deference, Justice La Forest advanced four arguments, none of which is persuasive. First, the Court adverted to the fact that section 9 (a) of the Code governs relations between private parties-relations which are themselves not governed by the Charter in general or by its equality guarantee in particular. ${ }^{101}$ Yet virtually all legislation regulates relations between private parties. This is no ground for deference, lest the Court automatically defer to virtually every instance of legislative discrimination banned by section 15. Moreover, human rights statutes do not simply regulate discrimination by private actors. They also prohibit discrimination by government agencies. ${ }^{102}$

The Court's second reason for deference is tied to its first. Applying a principle enunciated in a free expression case, the Court held that deference to the legislature is warranted under section 1 where, in enacting an impugned law, it attempts to balance the competing interests of different private groups in society. ${ }^{103}$ In contrast, where the government is in the role of a direct antagonist to constitutional rights, the Court held that such deference is not deserved. ${ }^{104} \mathrm{Mr}$. Justice La Forest held that the impugned mandatory retirement policies and enactments involve the government acting as balancer of competing private interests, and that the government's policies therefore merited deference. ${ }^{105}$

There may be occasions when certain Charter infringements should properly be harder to justify on account of the government's role as direct antagonist to a claimant's rights. However, this should have no role to play in a section 15 case. As the Supreme Court has acknowledged in both the statutory human rights and Charter section 15 contexts, a purposive approach to equality requires the Court's focus to be on the effects of impugned actions on a claimant, and not on the intent underlying them. ${ }^{106}$ An effects-focused approach to constitutional equality rights would not dismiss as less serious cases in which the government purports to discriminate in the interest of some other private group, short of a bona fide affirmative action program saved by Charter section 15(2), since it is the effect of government conduct, and not its intent, which should make the constitutional difference.

101. McKinney, [1990] 3 SCR at 312-15.

102. See, for example, Ontario Human Rights Code 1981, S0 1981, ch 53, §46 and Canadian Human Rights Act, RSC 1985, ch H-6, § 66.

103. McKinney, [1990] 3 SCR at 280-81, 285-86, applying Irwin Toy v Quebec (Attorney General), [1989] I SCR 927, 944.

104. Irwin Toy, [1989] I SCR at 994.

105. McKinney, [1990] 3 SCR at 287.

106. Simpsons-Sears, [1985] 2 SCR at 547; Central Alberta Dairy Pool, [1990] 2 SCR at 505; Andrews, [1989] 1 SCR at 173. 
Moreover, if judicial deference applied every time a section 15 contravention arises where government is balancing the interests of different groups in society, such deference would be triggered in virtually all section 15 cases that proceed to the section 1 stage. Legislative and governmental discrimination, on grounds set out in section 15 or on analogous grounds, frequently involves the advancement of some at the expense of others. The segregation of black schoolchildren or of children with disabilities in separate and inferior schools would automatically merit judicial deference if the government consciously does so to maximize the resources available for white or able-bodied children. Such an outcome would flatly contradict section 15's core values and would fail to reflect a "commitment to the unremitting protection" of the Charter's guarantees. ${ }^{107}$

Mr. Justice La Forest's invocation of judicial deference because of the legislature's role as balancer of competing interests is also highly questionable, in light of previous Supreme Court jurisprudence on the deference notion. Justice La Forest had previously questioned whether judicial deference to legislatures is appropriate in the equality context. ${ }^{108} \mathrm{As}$ well, the idea of judicial deference in section 1 analysis was, in effect, initially conceived to advance equality rights values, since it was to apply where the government attempts to protect vulnerable groups. ${ }^{109}$ In the mandatory retirement context, the government does not seek to protect a vulnerable group. ${ }^{10}$ Rather, it victimizes the elderly and invokes deference in its own defense to an equality claim. Accordingly, the Court's invocation of judicial deference contradicts both the letter and the spirit of its own deference doctrine.

Next, in support of his grant of judicial deference, justice La Forest relied on the U.S. Supreme Court holding in Williamson v. Lee Optical of Oklahoma, ${ }^{11}$ which the Supreme Court of Canada had previously invoked under Charter section 1 in a freedom of religion case. ${ }^{112}$ Lee Optical holds that government should be permitted to undertake legislative reform one step at a time, addressing itself to the aspect of a social problem which is legislatively deemed most pressing, without being second-guessed by the judiciary. ${ }^{113}$ Based on Lee Optical's judicial deference doctrine, Justice La Forest was prepared to defer to legislative judgments as to who should receive the benefits of legislative reform in the human rights context.

This is a serious misapplication of Lee Optical, wrenched out of its American jurisprudential context. Lee Optical rejected due process and equal protection challenges to state legislation granting a monopoly to opticians to

107. See Charter $\$ 15$.

108. R. v Edwards Books, [1986] 2 SCR 713, 795 (La Forest concurring)

109. Irwin Toy, [1989] 1 SCR at 101.

110. Justice Wilson properly makes this important point in her dissent in McKinney, [1990] 3 SCR at $402-03$.

111. 348 US 483,489 (1955).

112. Edwards Books, [1986] 2 SCR at 772.

113. Lee Optical, 348 US at 488. 
fit spectacles. ${ }^{114}$ It enunciated a strong principle of judicial deference to legislative decisions, but in the specific context of laws which distinguish between groups on grounds that are not inherently suspect and do not bear upon the exercise of fundamental rights. Under U.S. equal protection doctrine, such judicial deference clearly does not apply where a law either draws distinctions based upon suspect grounds ${ }^{115}$ or impedes the exercise of fundamental rights. Moreover, Lee Optical marks the U.S. Supreme Court's final, decisive retreat from the 1904 to 1937 regime of activist substantive due process, under which American courts had aggressively reviewed and often overturned substantive social-economic regulations on account of their interference with property and the freedom of contract.116 Lee Optical commanded strong judicial deference for such legislation, especially when challenged on substantive due process grounds.

If the Lee Optical approach to constitutional rights were properly applied under Charter section 15 in the Canadian context, the impugned mandatory retirement provisions and policies would merit strict judicial scrutiny, and not judicial deference. The mandatory retirement challenges involve both of the features which trigger the most exacting scrutiny. The age restrictions in the impugned human rights codes bear upon the exercise of a fundamental right, the access to human rights protection from age-based employment discrimination, and they discriminate based on age-a ground specifically enumerated in section 15.117 Moreover, these cases involved no substantive due process challenge based on assertions of property or contractual freedoms.

If Canadian courts give so sweeping an application to Lee Optical under section 1, Charter section 15 will quickly become a hollow shell. This is especially so in relation to section 15's guarantee of "equal benefit of the law without discrimination." Governmental benefits are always extended in a gradual, incrementalist fashion. If this simple fact merited judicial deference, even when the legislature's incremental extension involves clear discrimination on a ground which section 15 prohibits, then the Supreme

114. Id at 487.

115. Lawrence H. Tribe, American Constitutional Law $\S 16-7,16-14$, at 1465-74 (Foundation Press, 2d ed 1988).

116. The paradigmatic case of the era is Lochner $v$ New York, 198 US 45 (1905). The United States Supreme Court struck down a statute limiting the number of hours bakers could work as not within the reasonable exercise of the state's police power. The case exemplifies the Court's former willingness to invalidate economic regulations pursuant to the 14 th amendment's guarantee of due process.

117. This is not to argue for a "levels of scrutiny" approach to the grounds of discrimination enumerated in $\S 15$. This is simply to suggest that Lee Optical, if grafted onto Canadian law, would bring with it a continuum of scrutiny analysis. Even under such a system, however, it would be improper for age to receive only the lowest level of scrutiny. The grounds specifically enumerated in $\$ 15$ merit the most exacting scrutiny in light of the Charter's deliberate recognition of their importance to the pursuit of equality. 
Court will have gone a long way toward finding that section 15 has little practical force when government extends benefits to the public. ${ }^{118}$

Finally, Justice La Forest seems to suggest that deference is warranted in the human rights context since the purpose of the human rights code is the promotion of the ideal of equality - an ideal which takes time to achieve. ${ }^{119}$ It is true that the purpose of the code is the attainment of equality and that securing this absolute ideal will indeed take time. However, it could not plausibly be suggested that the purpose for denying the code's entitlement of freedom from age-based employment discrimination to persons aged sixtyfive and older is the attainment of equality. There is no rational connection between this wholesale disentitlement of the elderly and the promotion of equality.

By its judicial deference, the Court failed to take the contravention of Charter equality rights as seriously as it should have. Absent this deference, the impugned provisions might well have been found unconstitutional. If such deference pervades future section 15 cases when they reach the section 1 stage, governments will have an easy time justifying conduct which should be viewed as constitutionally suspect.

2. The Second Flaw. As the mandatory retirement decisions' second flaw, the court concluded that the purposes for the challenged mandatory retirement policies, and for the age definitions in the impugned human rights statutes, are sufficiently important to warrant the imposition of restrictions on elderly persons' equality rights. ${ }^{120}$ The Court identified these restrictions' purposes as (1) the provision of employment opportunities to young people, ${ }^{121}$ (2) the maintenance of flexibility in resource allocation and work force renewal, ${ }^{122}$ (3) the maintenance of settled workplace compensation schemes including pensions on retirement, ${ }^{123}$ and (4) the protection of the dignity of compulsorily retired employees, who are saved from demeaning performance appraisals. ${ }^{124}$ Justice La Forest doubted that the clearing of job openings for young persons was a sufficiently pressing goal to justify age discrimination, in light of its inherently discriminatory tenor. ${ }^{125}$ However, he found that the other objectives were sufficiently compelling under section 1.126

118. To a significant degree, this could constitute a de facto retreat to the approach that the Supreme Court had taken under the statutory Canadian Bill of Rights, under which the right to equality was ineffectual with regard to government benefits. See Bliss v Canada (Attorney General), [1979] 1 SCR 183. Such a retreat would directly conflict with the intention of the Charter's framers. Section 15 was specifically amended during the constitutional debate leading to the Charter's entrenchment to include the "equal benefit clause" in order to reverse the Bliss decision and to ensure that the equality guarantee fully applies to government benefits.

119. McKinney, [1990] 3 SCR at 318-19.

120. Id at 281 .

121. Id at $300-03$.

122. Id at 281 .

123. Id at 301-02.

124. Id at $282-83,314$.

125. Id at 302-03.

126. Id at 301-02. 
Once the Court found that a core reason for mandatory retirement and for the elderly's exclusion from human rights age discrimination protection is to provide job opportunities for young persons, the proper result would have been to declare that this goal is per se discriminatory and, as such, is an unconstitutional objective. It is intended to deny work to elderly persons, on account of their age, for the very reason of giving jobs to the young. This is not to suggest that every legislative age distinction ipso facto has an unconstitutional goal that is outside section l's purview. Rather, it simply means that where the legislature makes an adverse age distinction for the very aim of taking away opportunities from one age group to give to another, it engages an unconstitutionally discriminatory motive, except where defensible under section $15(2)$ as a bona fide affirmative action program.

Longstanding human rights authority holds that an action is discriminatory even if only one of its motivating reasons is impermissible, such as sex, age, or race, although there may have been other nondiscriminatory reasons motivating the action. ${ }^{127}$ Once an act is tainted by a discriminatory purpose, it is no answer that there were other causes for the act. Otherwise, one could effectively secure discriminatory aims by carefully piggy-backing them on top of less questionable goals. In light of this critical equality principle, the impugned mandatory retirement policies and provisions should have been found to have impermissible purposes, and hence to be unconstitutional, regardless of any additional objectives for these measures posited by their defenders.

This result would comport with a theme in two early Charter cases where section 1 was seen as unavailable to government where a law had as its purpose an aim which is directly contrary or inimical to the Charter right in question. In Quebec (Attorney General) v. Quebec Association of Protestant School Boards et al., 128 the Court unanimously overturned a Quebec statute limiting access to English education as contrary to Charter section 23's minority language education rights guarantee. The Court held that section 1 could not be invoked where the law's purpose was directly contrary to the section 23 entitlement. The Court did not engage in any assessment of the law's reasonableness or demonstrable justification.

In Regina v. Big $M$ Drug Mart, ${ }^{129}$ Justice Wilson, in a concurring opinion, ruled that a law is unsalvageable under section 1 if its purpose is incompatible with the Charter. There, the federal Lord's Day Act, forcing retail stores to close on Sundays, was found to infringe the freedom of religion and to be unsustainable under section 1 because its objective was the compulsion of religious observance-a goal inimical to the Charter's core reason for guaranteeing freedom of religion. It was not simply a matter of finding that the law's purpose was insufficiently weighty to comport with section 1 . The law's purpose was itself tainted as being constitutionally intolerable. Because

127. Cameron v Nel-Gor Castle Nursing Home, 5 CHRR D/2170.

128. [1984] 2 SCR 66.

129. [1985] I SCR at 362. 
the law had an unconstitutional purpose, it was unnecessary to examine whether its means to attain that goal were proportional to its objective. Where a legislative goal is unconstitutional, it simply cannot be pursued consonant with Charter section 1 regardless of the means employed.

The same flaw can be found with the impugned mandatory retirement provisions and policies. The legislature's goal, youth employment at the expense of the elderly, is an unconstitutional aim. This should have tainted the entire section 1 defence and sent the legislature back to the drawing board.

The Big M Drug Mart and Protestant School Boards decisions differ factually from the mandatory retirement situation. These earlier cases did not involve a law with multiple purposes, only one of which is unconstitutional. They involved "single purpose" laws, where the single purpose was unconstitutional. However, this distinction should make no difference lest a legislature be able to piggy-back legislative purposes to enable it to do that which the Constitution forbids.

3. The Third Flaw. The mandatory retirement decisions' third flaw was that the Court failed to effectively apply the section 1 requirement that a law infringing a Charter right must be shown to impair that right as little as possible, consistent with the promotion of the impugned law's pressing and substantial objectives. ${ }^{130}$ Had this requirement been effectively applied the human rights legislation before the Court and most, if not all, of the mandatory retirement policies in issue would have failed to pass section 1 muster.

The minimal impairment branch of the section 1 test is critically important to the Charter's practical success in protecting civil liberties and in constraining improper government conduct. It provides that Charter rights can be infringed only in specific situations where it is clearly necessary to do so to promote vital government ends. Where it is not necessary to take away a person's Charter rights, it cannot be demonstrably justified to do so in a free and democratic society which has a fundamental constitutional commitment to these rights.

Of the section 1 test's various components, the least impairment requirement most effectively infuses the Charter into the daily operations of government. In deciding on new initiatives, government agencies frequently review and choose from among a range of options. The least impairment requirement compels government actually to assess each option's impact on Charter rights and to select that option which threatens those rights the least, consonant with the attainment of critical policy goals. Such governmental reflection is essential to head off Charter infringements before they ever occur. The least impairment requirement directs governments to tread extremely carefully and hesitantly when their actions potential bear upon

130. R. v Oakes, [1986] I SCR at 139. 
constitutional rights. It ensures that the lofty rhetoric frequently advanced in support of impugned legislation and government action is tempered by the need to link the specifics in these laws directly and intimately to the actual achievement of laudatory governmental goals.

In the mandatory retirement decisions, the Supreme Court held that the minimal impairment requirement is met by an Ontario Human Rights Code provision which takes away from all persons over the age of sixty-five any recourse to the human rights commission for age-based employment discrimination. ${ }^{131}$ Yet, even if one accepts the importance of mandatory retirement policies at age sixty-five in workplaces which have the quid pro quo of post-retirement pension schemes, and whose labour turnover is primarily triggered through retirement, the flat denial of any legal protection of agebased employment discrimination whatsoever in Ontario respecting any employer whatsoever cannot meet the section 1 minimal impairment requirement. As the dissenting opinions properly indicate, not every employer who fires some or all of its employees at age sixty-five has given either strong assurances of job security up to age sixty-five or a pension plan for them on retirement. ${ }^{132}$ There may be no quid for many who are saddled with the mandatory retirement quo. As well, not every employer who terminates some or all employees at age sixty-five must do so to free up job openings for younger persons. The majority first held that mandatory retirement is justified in the peculiar, rarified context of university professors who are tenured, and whose work requires the strong protection for academic freedom. Then it projected this entirely unique situation onto the entire workforce-a wholly untenable analogy. ${ }^{133}$

The government's policy goals also do not justify the denial to persons over sixty-five of any human rights protection whatsoever concerning agebased employment discrimination. For example, a 50-year-old employee can file an age-discrimination human rights complaint if his or her employer pays him or her less per hour than a 30-year-old employee on grounds of their different ages. A 66-year-old employee cannot make a similar claim if he or she is paid less than an employee under sixty-five. This is so simply because he or she is over sixty-five.

A legislature wishing to preserve bona fide mandatory retirement policies, for the reasons recognized by the Court, could have allowed for age discrimination claims by persons over age sixty-five in human rights legislation. A narrowly crafted exemption could have been enacted, allowing for age distinctions which are bona fide and reasonable occupational requirements, including the maintenance of a bona fide 65-year mandatory retirement policy, in the case of employers whose employees have strong job security guarantees and post-retirement pension plans. Such a provision would have impaired Charter equality rights far less than the provisions

131. McKinney, [1990] 3 SCR at 315.

132. Id at 405-06 (Wilson dissenting); id at 434 (l'Heureux-Dubé concurring).

133. Id at 305-06. 
impugned in these decisions. It could be easily formulated by a legislature and readily implemented by human rights commissions and boards. It would have achieved the legislative goals of maintaining bona fide mandatory retirement programs at age sixty-five without sacrificing the Charter rights of employees further than was needed. ${ }^{134}$

Moreover, the Supreme Court could have readily so found without stepping outside its judicial role. Such a broad-brush principle could have been enunciated without drawing the Court into the minutiae of legislative fine line-drawing. The Court has been willing to express such an opinion when it has found legislation invalid in previous cases. ${ }^{135}$

4. The Fourth Flaw. The mandatory retirement decisions' fourth and perhaps most vexing flaw is that they are rooted in an unfair stereotyping of the elderly. As one factor weighed in the section 1 balance, Justice La Forest noted that age can correlate with ability since with the advancing of age comes a loss of capacity. ${ }^{136}$ The Court attempted to soften this point by acknowledging that this impact of aging will vary from individual to individual. ${ }^{137}$ Nevertheless, the Court clearly infused this age/ability factor into its reasoning. It viewed the loss of ability with age, explicitly or tacitly, as rendering compulsory retirement at age sixty-five an effective means of promoting a competent work force, and as making mandatory retirement potentially less invidious as a form of discrimination. ${ }^{138}$

This kind of stereotyping lies at the heart of much of the discrimination and inequality confronting the elderly, as well as women, disabled persons, racial minorities, and other disadvantaged groups in society. The eradication of such stereotyping, and of exclusionary practices motivated by it, is a core objective of both human rights legislation and section 15 of the Charter. The best remedy for stereotypical generalizations is a potent legal requirement that individuals be assessed on their individual merits and not on categorical judgments tied to personal characteristics.

As the Court's own judgment amply demonstrates, such stereotyping is a core factor motivating mandatory retirement practices. ${ }^{139}$ For the Court itself to articulate such stereotypes is enormously problematic. For it to advance such stereotypes as a partial justification for a denial of equality with respect

134. This is not to suggest that mandatory retirement as such would be constitutionally justified even if preserved by a more narrowly drafted Human Rights Code provision. That question is beyond the scope of this article. The point to be made here is simply that even if mandatory retirement can at times be constitutionally justified, the Court's "least impairment" analysis is still fundamentally flawed.

135. See, for example, $R$. v Morgentaler, [1988] I SCR 30; Hunter v Southam Inc., [1984] 2 SCR 145.

136. McKinney, [1990] 3 SCR at 289, 297-98 (La Forest).

137. Id at 289.

138. See, for example, id at 305-06.

139. See id at 289; see also Etobicoke, [1982] I SCR at 210 (invalidating a municipal fire department's policy of compulsorily retiring fire fighters at age 60, as impermissible age-based employment discrimination under the Ontario Human Rights Code). In Etobicoke, a unanimous Court denounced as merely impressionistic and insufficient the fire department's testimony that fire fighting is a "young man's game." 
to a fundamental right, such as access to human rights protection, constitutes a dramatic step backward on the road to equality.

In an apparent attempt to reduce the force of his reference to an age/ability correlation, Justice La Forest noted in passing that mandatory retirement does not purport to be justified by an assertion that all persons over sixty-five suddenly are incapable of continuing in productive employment. 140 Indeed, he had opined at length elsewhere about mandatory retirement's justification as a quid pro quo for guarantees of job security and pension entitlements. ${ }^{141}$ Yet this does not undo the force of his clear reliance on stereotypes about the elderly as part of his section 1 analysis. After all, if mandatory retirement was justifiable solely on the basis of the quid pro quo rationale and the revitalization of the work force objective, it would have been entirely unnecessary to refer to asserted correlations between age and ability as part of the section 1 analysis.

Moreover, in the mandatory retirement opinion addressing challenges to the compulsory termination of doctors' hospital privileges at age sixty-five at Vancouver General Hospital, the Court squarely and centrally relied on the age/ability stereotype under section 1 . It found that mandatory retirement of doctors at sixty-five, at least in so far as their hospital privileges are concerned, is rationally connected to the hospital's asserted goal of ensuring competence of staff and high quality medical services. ${ }^{142}$ In this light, the Court's effort to deny its reliance on such an age/ability stereotype becomes puzzling.

Indeed, the Court's approach to the age/ability stereotype in this case is most unfathomable. The Court ruled that in such settings mandatory retirement is an appropriate and narrowly-tailored means to ensure the best quality health care for patients. ${ }^{143}$ Yet, on the facts apparently before the Court, the hospital in question had undertaken an annual peer review of doctors' abilities, regardless of the mandatory retirement scheme. ${ }^{144}$ Unless it were established that such ongoing peer review was incapable of rooting out doctors whose skills had degenerated to an unacceptable level, it is hard to see what mandatory retirement at sixty-five could add. If anything, it would only force out of work those doctors who had, on peer review, already been found to be competent to continue in practice-a consequence which cannot be tied rationally to the goal of protecting patients' health.

140. McKinney, [1990] 3 SCR at 297 (La Forest).

141. Id at 303-04, 307, 310-11, 313-14.

142. Stoffman v Vancouver General Hospital, [1990] 3 SCR at 524-26 (La Forest).

143. See, for example, id at 528-29.

144. The various opinions on this point are confusing. Justice L'Heureux-Dube states that the hospital now undertakes these annual reviews. Id at 563-65. Justice Wilson states that the hospital previously undertook these annual reviews until 1980, when, for administrative convenience reasons, it replaced this process with the impugned mandatory retirement scheme. Id at 554 . Justice La Forest, for the Court, makes no mention of this at all. What is apparent in any event is that the hospital either now has, or recently has had, an annual review for doctors. If it has none any longer, one would question the hospital's commitment to the protection of patients' health through the ongoing maintenance of a sufficiently competent medical staff. 
Additionally, in McKinney, the Court emphasized that mandatory retirement serves in part to protect the dignity of aging employees by helping them to avoid the embarrassment of performance reviews and by instead allowing them to continue their employment up to age sixty-five even if they are not performing up to snuff. ${ }^{145}$ Such a rationale, wedded to the age/ability correlation, cannot rationally apply in the Vancouver General situation for two obvious reasons. First, the hospital has required annual performance reviews. Mandatory retirement therefore does not remove from doctors the asserted indignity of such reviews. Second, if the Court's primary concern in Vancouver General was with the paramount goal of safeguarding patients' health as it claimed, it would make no sense to endorse a mandatory retirement scheme on a rationale that it enables doctors to continue working up to age sixty-five even if their talent is declining. A heart surgeon presumably should not be left in the operating room at age sixty-four for another year, while his or her surgical skills are deteriorating, as a quid pro quo for mandatory retirement at age sixty-five, if health protection is so important a goal.

The Court's reliance on such stereotypes about the elderly is fundamentally inconsistent with section 15's central purposes, as the Court had previously identified them. In Andrews and Turpin, the Court held that section 15 aims to protect persons from disadvantageous treatment on account of stereotypes and broad-brush generalizations based on such personal attributes as sex, religion, disability, or age. ${ }^{146}$ Section 1 cannot be properly invoked to justify the state's imposition of disadvantageous treatment on the basis of the stereotypes which section 15 aims to eradicate from the government's conduct. Otherwise, section 1 will become the source for the Charter's perpetuation of a central cause for governmental discrimination rather than becoming a key component in the eradication of its root causes.

5. The Fifth Flaw. The fifth flaw in the Court's analysis was the implicit view that the age discrimination inherent in mandatory retirement is not motivated by prejudice. From the overall tenor of the opinion of the court, this assumption can be seen as diminishing the severity of age discrimination. It accordingly would diminish the justificatory burden on the government and other bodies defending these practices. To the extent that such a consideration actually influences the Court, it can be seen as an outdated approach to equality rights which bodes ill for many equality seekers, such as disabled persons and women. As the Supreme Court had recognized in its equality rulings in the 1980s, any meaningful enforcement of human rights requires a court's attention to be fixed squarely on the effect of impugned action on the victim of the discrimination, and not upon the intent of the discriminator.

145. McKinney, [1990] 3 SCR at 286-87 (La Forest).

146. Andrews, [1989] I SCR at 174-75; Turpin, [1989] I SCR at 1331. 
To the extent that the Court viewed discrimination as more tolerable if it is well-meaning, and not motivated by prejudicial animus, it would implicitly treat sex-based and disability-based discrimination as somehow more tolerable, or less discordant, under the Charter. This is because the vast preponderance of discriminatory practices against women and disabled persons are not motivated by hatred against those disadvantaged groups. Rather, they are frequently motivated by well-intentioned paternalism or simple outdated stereotypes. Such stereotyping, albeit unmotivated by prejudice or animus, must be construed as an aggravating factor under section 1 necessitating even greater justification if the government is to excuse its discriminatory conduct. To take the Supreme Court's apparent approach is effectively to condone constitutionally one of the greatest sources of inequality.

6. The Sixth Flaw. The Court's final flaw was that it entirely confused the concepts of direct discrimination and unintentional or adverse effects discrimination, and erroneously called mandatory retirement "adverse effects" discrimination. ${ }^{147}$ According to longstanding Canadian equality doctrine, direct discrimination occurs when a person or group is denied a benefit or is subjected to a special burden explicitly because he or she has a particular protected personal characteristic, such as age, sex, religion, or disability. ${ }^{148}$ In such cases, the discrimination is presumed to be purposive or intentional simply because the government or other discriminating party made the protected characteristic a reason for denying the benefit or imposing the burden. For example, if a law states that no black person may obtain a job in the provincial public service, it amounts to direct, intentional discrimination, precisely because the law enumerates the racial classification on its face. One need not prove any malice underlying this exclusionary, overtly race-based classification to establish that it is intentionally discriminatory. 149

In contrast, "adverse effects discrimination" (which is sometimes called systemic discrimination, unintentional discrimination, or indirect discrimination) occurs when a requirement universally imposed appears neutral on its face, but has a disproportionate impact on a protected minority. The classic example is an employer's work rule requiring that all employees work Saturday shifts, apart from other weekday assignments. This rule does not purport on its face to discriminate because of religion, and indeed applies equally to all employees regardless of their religions. However, the rule has the effect of precluding Seventh Day Adventists from working for that employer because Adventists adhere to a core religious teaching that gainful employment is prohibited on their Sabbath, which is observed from Friday sunset to Saturday sunset. The Saturday work rule is said to have adverse and

147. McKinney, [1990] 3 SCR at 279 (La Forest).

148. Tarnopolsky \& Pentney, Discrimination and the Law at 4-19 through 4-22 (cited in note 9).

149. Cameron v Nel-Gor Castle Nursing Home, 5 CHRR D/2170. 
discriminatory effects on Adventists, and hence is prima facie discriminatory because of religion. ${ }^{150}$

Applying this two-category approach, the mandatory retirement regimes in issue before the Supreme Court were obvious examples of direct, intentional age-based discrimination. One's employment and one's access to the protection of human rights legislation from age-based employment discrimination are each denied for the explicit reason of one's age. Persons over the age of sixty-five are deliberately singled out for worse treatment.

Yet, in McKinney, the Court did not hold that the age discrimination in the impugned mandatory retirement policies and provisions amounted to intentional or purposive discrimination. Instead, it held, without explanation, that it only constituted adverse effects discrimination. ${ }^{151}$ This characterization is quite erroneous and is impossible to square with clear, longstanding human rights and equality doctrine. The impugned mandatory retirement policies and provisions are the most obvious examples of direct discrimination and cannot possibly be characterized as adverse effects discrimination. This fundamental misconception of equality rights is especially troublesome since it could be explained (though not justified) only by an implicit, though unarticulated view that discriminatory intent exists only where deliberate age-based adverse treatment is motivated by overt malicious animus. This view would be a radical retrenchment from the progress that has slowly been achieved in human rights and equality rights jurisprudence.

In summary, the mandatory retirement judgments constitute a substantial downward plunge on the roller coaster ride of equality rights in Canada, both because of the Court's validation of the wholesale relegation of elderly persons to second-class, impoverished status in the employment context, and because of the Court's depletion of important section 1 principles which had promised to serve equality so well. The Court, at least in the constitutional context, has strongly implied that it is reverting to the ineffectual approach to equality which predominated in the Canadian judiciary throughout the bulk of this century. This result flows from the subtle intricacies of the section 1 test rather than through a wholesale and open repudiation of equality as a norm meriting serious judicial attention.

\section{Regina v. Sheldon S.}

Along with Hess and the mandatory retirement decisions, the Supreme Court's third 1990 equality decision could substantially curtail section 15's reach, even before resorting to section 1 becomes necessary. In Regina $v$. Sheldon $S .,^{152}$ the Court rejected an accused youth's section 15 challenge to section 4 of the Young Offenders Act, ${ }^{153}$ a provision which granted each

150. See Simpsons-Sears, [1985] 2 SCR at 558; Central Alberta Dairy Pool, [1990] 2 SCR 489; see also Ont Human Rts Code $\S 10$ (1981).

151. McKinney, [1990] 3 SCR at 279 (La Forest).

152. R. $v$ Sheldon S., [1990] 2 SCR 254

153. Young Offenders Act, SC 1980-81-82-83, ch $110 \S 4$. 
provincial Attorney General the discretion to establish alternative measures programs for children and youth charged with criminal offenses. Only Ontario had declined to establish an alternative measures program under this provision. The accused claimed that Ontario's failure to exercise this discretion discriminated against young persons in Ontario as compared to those in other provinces.

That the Court unanimously rejected this section 15 argument is itself above reproach since differential treatment based on province of residence (or in this case, province of alleged offence and of prosecution) is not a personal characteristic analogous to the grounds enumerated in section 15 . Indeed, in dicta, the Court properly noted this fatal flaw with the section 15 claim. However, it chose to dispose of the constitutional challenge on far broader and highly problematic grounds.

The Court held that section 15 cannot be invoked to attack an Attorney General's action or inaction under the impugned provision since section 15 protects against only discrimination in law. Here, the law was not the source of the discrimination since the provision in question did not compel Ontario's Attorney General to refuse to implement an alternative measures program for young offenders. By this, the Court clearly implies, if it does not overtly proclaim, that section 15 is available to attack discrimination only where a law itself requires the imposition of the specific action which constitutes inequality. Section 15 cannot therefore ever be engaged where the inequality arises from a public official's exercise of discretion, even when that discretion is clearly conferred on the public official by a law.

Yet, section 15's very wording commands a very different approach to the Charter's ban on governmental discrimination. It goes out of its way to guarantee equality "before" and "under" the law, as well as equality in the "protection" and "benefit" of the law. ${ }^{154}$ This wording is designed to ensure that section 15 targets both discrimination in the substance or content of the law, as well as inequalities in the law's actual administration by public officials. How a public official exercises his or her statutory discretion is a core component of the way in which a law is practically administered, or, in section 15 's terms, in how one is treated "before" and "under" the law. The word "law" in section 15 is not dispositive of the question before the Supreme Court in Sheldon S. Rather, the words "before," "under," "protection of," and "benefit of," juxtaposed with the word "law," 155 are critical, and were evidently overlooked by the Supreme Court.

Sheldon S., if not reversed or construed very narrowly, would have the practical effect of immunizing from Charter scrutiny the vast preponderance of government action. This is because the bulk of government action is not specifically compelled by a mandatory directive in a law. Rather, it is taken under permissive, discretion-conferring legislative provisions, akin to those

154. See note 40 .

155. See id. 
found in the law under consideration in Sheldon $S$. For example, if a minister has open-ended statutory discretion to hire his or her staff, and is not compelled by statute to hire any particular individual, a ministerial decision to reject a black person's application on account of his or her race is untouchable under Charter section 15. Ironically, even the discredited equality rights guarantee in the statutory Canadian Bill of Rights might be more able to reach such conduct than is Charter, at least if it occurs in the federal public service, since virtually the only discrimination which that guarantee addresses is inequality in the administration of the law, and not in the law's substantive content. Section 15 was intended to incorporate both the limited protection included in the Canadian Bill of Rights and much more. Yet after Sheldon $S$, it is questionable whether it can achieve this goal.

The mandatory retirement, Sheldon $S$, and Hess decisions together suggest that equality rights protection under the Charter faced serious new peril in 1990. However, the year ended with an ironic glimmer of hope for legal protection from discrimination when the equality rights roller coaster took a peculiar turn. At year's end, the Supreme Court released a series of decisions rejecting freedom of expression challenges to hate propaganda laws under the Charter. ${ }^{156}$ The Court held that the dissemination of messages which promote hatred against identifiable racial or religious groups infringe the freedom of expression as guaranteed by Charter section 2(b). However, these legal restrictions on hate-mongering were upheld under section 1 . In issue were Criminal Code provisions banning hate propaganda against racial or religious minorities ${ }^{157}$ and a Canadian Human Rights Act provision prohibiting the repeated use of the telephone to disseminate messages likely to promote hatred against such groups. ${ }^{158}$ The Court held that the aim of these laws-the promotion of equality and full participation in society for racial, religious, and other minorities-is so central a tenet of a free and democratic society that its furtherance can warrant the imposition of civil and even criminal law restrictions on free speech. This was so due to the discrimination which hate-mongering can cause and the psychological trauma which minorities can suffer when targeted by such expression.

A marked departure from the American constitutional treatment of freedom of expression, ${ }^{159}$ the hate propaganda cases strongly suggest that the Court retains a powerful commitment to the goal of equality rights protection. Yet these decisions appear profoundly ironic in light of the mandatory retirement rulings. Taken together, these cases suggest that the Supreme

156. R. $v$ Keegstra, [1990] 3 SCR 697 (upholding a high school teacher's hate propaganda conviction for teaching his class virulent anti-Semitic theories of history); $R$. $v$ Andrews, [1990] 3 SCR 870 (upholding a criminal conviction for breach of the hate propaganda provisions of the Criminal Code); Canada Human Rights Commission v Taylor, [1990] 3 SCR 892 (upholding contempt conviction for breach of an order, pursuant to the Canadian Human Rights Act, banning certain anti-Semitic and racist messages on a White Supremacist Party's telephone answering machine).

157. See Crim Code, RSC 1985, ch C-46§319.

158. Can Hum Rights Act RSC 1985, ch H-6 §13.

159. See, for example, Village of Skokie $v$ National Socialist Party of America, 51 IIl App 3d 279, 366 NE2d 347 (1977); Doe v University of Michigan, 721 F Supp 852 (ED Mich 1989). 
Court views equality to be so important an aim that it will sacrifice free speech to advance this goal, even though it has repeatedly recognized that free speech is itself fundamental to a democracy. ${ }^{160}$ Yet, when called upon directly to enforce equality rights in the mandatory retirement cases, the Court quickly deferred to legislatures and gave judicial sanction for the stereotyping of a disadvantaged minority. It appears that, as of 1990 , the Court will invoke equality as a reason to defend legislation and restrict constitutional free speech, but it is far less willing to invoke equality to overturn legislation and to enforce constitutional anti-discrimination guarantees.

If one views 1990's landmark human rights case, Christie v. Alberta Dairy $P o o l,{ }^{161}$ together with the hate propaganda cases and in contrast to Sheldon $S$., Hess, and the mandatory retirement decisions, one finds an apparently confused and ambivalent, if not entirely contradictory, judicial attitude toward the value of equality. In Christie, the Court unanimously reversed its five-yearold human rights code decision which effectively had held that only some of Canada's human rights statutes impose a duty on employers, landlords, and service providers to accommodate the needs of women, disabled persons, and other disadvantaged minorities, where such accommodation is needed to ensure equality of opportunity. ${ }^{162}$ Christie's statutory interpretation ruling reflected a continued dedication to equality protection, at least through the interpretation of human rights statutes. It also reflected profound judicial courage and candor, in that the Court, by explicitly overturning its previous authority, overtly recognized that its previous decision was simply erroneous and indefensible.

\section{VI \\ Conclusion-The Road Ahead}

At this important crossroad on the path to full equality rights protection, there are two possible routes which the Supreme Court can choose to follow. By the first route, it can explicitly or implicitly move away from Hess and the mandatory retirement decisions' approach to equality rights. This the Court could do effectively since the most problematic findings in those decisions were supported only by a minority of the justices who now remain on the Court. Hess and the mandatory retirement rulings could be relegated to a position of minimal precedential significance on account of their profound departure from important equality principles. Similarly, Sheldon S.'s restriction of section 15's ban on discrimination to inequalities compelled by a law could be disapproved as effectively unnecessary to the case's resolution since a simple application of the Andrews/Turpin approach to section 15 would have disposed of the case most handily.

160. See, for example, Irwin Toy, [1989] 1 SCR at 969.

161. See Central Alberta Dairy Pool, [1990] 2 SCR 489.

162. See Bhinder, [1985] 2 SCR 561. 
By the second route, the Court could stick to the downward path charted in the Sheldon S., Hess, and mandatory retirement decisions. In so doing, it would leave Canada's racial minorities, women, disabled persons, and other analogous equality-seeking disadvantaged groups with little practical protection under the hitherto-promising Charter of Rights. If they are able to persuade the Court to adhere to the Andrews/Turpin approach to the interpretation of section 15, equality-seekers will meet with potentially extreme judicial deference for legislation and government action under section 1 , replete with government's ability effectively to piggyback invidious discriminatory motives on top of more laudable aims. Governmental discrimination can be fortified by stereotyping and paternalism toward disadvantaged groups, and the government's section 1 obligation to tailor its laws and actions bearing on section 15 rights carefully so as to impair these rights as little as possible will have dubious practical impact.

The preferable direction is for the Supreme Court to steer a clear ascent back to the promising heights of Andrews and Turpin, and to leave Hess, Sheldon $S$., and McKinney far behind. Section 1 of the Charter should not tolerate, much less countenance, any stereotyping of the elderly, women, persons with disabilities, or anyone else protected by section 15 . Governmental discrimination should be actionable under the Charter whether it is compelled by a law or simply imposed by the action of a public official or governmental agency. In section 15 cases which proceed to section 1 , deference to legislatures should be the very rare exception. The original Oakes formulation of the section 1 test should be applied with full force in equality cases, much as it has remained in force in at least some other constitutional contexts. ${ }^{163}$ Perhaps most importantly, the Supreme Court's fast retreat from the "least impairment" requirement should be reversed, since it is this aspect of the section 1 test which ultimately makes legislatures and governments live up to the Constitution's convictions and which tests their section 1 justifications for their true validity. Such measures can help ensure that the Supreme Court's vital infusion of equality as a core legal value in Canada in the 1980s can pack a practical punch and can relegate to the history books Canada's unfortunate, longstanding judicial history of discrimination that is unrecognized and equality that is unprotected.

163. See, for example, $R$. v Morgenlaler, 12 DLR (4th) 502 (Ont CA 1984); Hess v R., [1990] 2 SCR 906. 
